\title{
Binary biosorption of Cadmium(II) and Nickel(II) onto planococcus sp. isolated from wastewater: Kinetics, equilibrium and thermodynamic Studies
}

\author{
Ashraf A Hoseini ${ }^{1}$, Hami Kaboosi ${ }^{1}$, Salman Ahmady-Asbchin ${ }^{2 *}$, Esmayel ghorbanalinezhad ${ }^{3}$ and Fatemeh P Ghadikolaii ${ }^{4}$ \\ ${ }^{1}$ Department of Microbiology, Ayatollah Amoli Branch, Islamic Azad University, Amol, Iran \\ ${ }^{2}$ Department of Microbiology, Faculty of Basic Science, University of Mazandaran, Babolsar, Iran \\ ${ }^{3}$ Department of Microbiology, School of biology sciences, Islamic Azad University, Tonekabon branch, Tonekabon, Iran \\ ${ }^{4}$ Department of Biology, Qaemshahr Branch, Islamic Azad University, Qaemshahr, Iran
}

\begin{abstract}
In this present study the effects of $\mathrm{pH}$, temperature, single and dual metal ion concentrations, dose of Planococcus biomass and desorption agents on the uptake of $\mathrm{Cd}(\mathrm{II})$ and $\mathrm{Ni}(\mathrm{II})$ was measured using atomic absorption spectrophotometry. To show surface adsorption of bacteria, SEM-EDX and FTIR analysis were done before and after metals adsorption. The maximum biosorption capacity of Planococcus sp determined as $0.67,0.48 \mathrm{mmol} \mathrm{g}^{-1}$ for cadmium(II) and as $0.58,0.47 \mathrm{mmol} \mathrm{g}{ }^{-1}$ for nickel(II) for single and binary ion situation. The correlation coefficient for the second-order kinetic model was 0.993 . The Langmuir and Freundlich isotherm models were also applied to the equilibrium of system and data were better fitted with the Langmuir isotherm.
\end{abstract}

\section{Introduction}

Environmental contamination with heavy metals is a serious problem due to their toxicity to human, plants, and animals. Wastewaters from a variety of industry are an important source of environmental pollution [1]. Water pollutants include organic and inorganic substances. One of the important pollutants is heavy metals that directly or indirectly come into the water sources and wastewater cause death and disease in the world, so it is necessary to remove it from water and waste-water [2]. Also, heavy metals constitute dangerous environmental pollution due to their high toxicity and tendency to migrate and bioaccumulate in the food chain [3]. Unlike organic pollutants, inorganic pollutants such as heavy metals cannot be degraded and are accumulated over time in the environment which make too many problems $[4,5]$.

The ever-lower limits of heavy metal levels in water and wastewater discharged into the environment require new and efficient methods to remove them. Today, various methods have been applied to remove dissolved metal ions from aqueous solutions and include flocculation, precipitation, electrolysis, crystallization, adsorption, chemical precipitation (chemical and physical method) and biological while physical and chemical methods are not suitable due to the high cost and secondary pollutions which they produce have low inefficiency (especially at low concentrations) offer no regeneration, need large amount of chemicals, whereas the biology method is more appropriate is cost-benefit and friendly to the environment [6,7]. In recent years, biological methods such as biosorption, bioaccumulation processes have been considered as novel, economic, efficient, and eco-friendly alternative treatment technologies for the removal of heavy metals from contaminated wastewaters generated from various industries. Biosorption, bioaccumulation and biodegradation have been already utilized by yeast, fungi, algae, bacterium, and cyanobacteria $[8,9]$.
Among organisms and microorganisms, bacteria play an important role in removing toxic and heavy metals. Because it can live everywhere, does not make sludge, and is easily cultivated. Both dead and live bacteria can remove pollutants where dead bacteria have higher pollutant removal level than living bacteria because of extensive area [10-12]. Metal ions removal by bacterial biomass is a complex process that depends on the chemistry of the metal ions, cell wall composition of bacteria, cell physiology, and physicochemical factors such as $\mathrm{pH}$, temperature, time, ionic strength and metal concentration $[13,14]$. The functional group that have known is carboxyl, amine, hydroxyl, amide, thiol, phosphate in the cell wall of bacteria an important role in biosorption. As they are negatively charged and abundantly available, carboxyl groups actively participate in the binding of metal cations [15-17].

In general, all types of biomaterials used for biosorption were found to have good biosorption capacities towards all types of metal ions. The metal ion-binding mechanism in biosorption may involve different processes such as complexation, coordination, electrostatic attraction, or microprecipitation; whereby ion exchange plays a major role in the binding of metal ions by adsorbent biomass [18]. The aim of the present study is to investigate the experimental and theoretical removal of $\mathrm{Ni}(\mathrm{II})$ and $\mathrm{Cd}(\mathrm{II})$ ions as single and binary from simulated wastewater using Planococcus sp. as a bio sorbents.

${ }^{\star}$ Correspondence to: Salman Ahmady-Asbchin, Department of Microbiology, Faculty of Basic Science, University of Mazandaran, Babolsar, Iran, Tel: +98(0)35305253, Fax: +98(0)9113285176; E-mail: sahmadyas@yahoo.fr

Key words: binary biosorption, planococcus, Heavy metals, Isotherm, FTIR

Received: April 02, 2020; Accepted: April 17, 2020; Published: April 20, 2020 


\section{Materials and methods}

\section{Preparation of bacteria and metals solutions}

Bio sorbent for the removal of metal ions from aqueous solutions was prepared using the Planococcus sp. (Gram-positive, cocci form, motile, and non-spore forming bacteria) that isolated from wastewater (Babolrood River in Iran). The isolate was purified and identified according to Bergey's manual (2005) [19]. The bacterial strains were cultured was grown in a $250 \mathrm{ml}$ Erlenmeyer flask containing $50 \mathrm{ml}$ medium glucose mineral salts (GMS = yeast extract 3.0, $\mathrm{Na}_{2} \mathrm{PO}_{4} 5.35$, $\mathrm{NH}_{4} \mathrm{Cl}$ 2.67, Glucose 10.0, $\mathrm{FeSO}_{4} .7 \mathrm{H}_{2} \mathrm{O} 0.4, \mathrm{MnSO}_{4} .7 \mathrm{H}_{2} \mathrm{O} 0.075$, $\left.\mathrm{MgSO}_{4} .7 \mathrm{H}_{2} \mathrm{O} 0.1, \mathrm{CaCl}_{2} .2 \mathrm{H}_{2} \mathrm{O} 0.1 \mathrm{~g} / \mathrm{l}, \mathrm{pH} 7.0\right)$ at $37^{\circ} \mathrm{C}$ and $150 \mathrm{rpm}$, for $72 \mathrm{~h}$, then harvested by centrifugation at $10000 \mathrm{rpm}$ for $15 \mathrm{~min}$ at room temperature and washed twice with normal saline.

Single and binary metal concentrations in the relevant samples were determined by an atomic absorption spectrophotometer (Chem., Tech, Analytical CTA 2000). The liquid phase was separated from the adsorbent by a filtration system using $0.45 \mu \mathrm{m}$ membranes. Nickel and Cadmium solutions with different initial concentrations $(0.4-1.4 \mathrm{mg} / \mathrm{L})$ were prepared by dissolving $\mathrm{NiCl}_{2} \cdot 6 \mathrm{H}_{2} \mathrm{O}$ and $\mathrm{CdCl}_{2} \mathrm{H}_{2} \mathrm{O}$ adequate dilution of the stock solution with deionized water for single system and binalry system respectively .Solutions of sodium hydroxide $\mathrm{NaOH}$ $(0.1 \mathrm{M})$ and nitric acid $\mathrm{HNO}_{3}(0.1 \mathrm{M})$ were used for $\mathrm{pH}$ adjustment [18].

\section{Biosorption of single and binary component heavy metal solution}

The effect of different items were determined as follow: $\mathrm{pH}$ (3-12), isotherm (single and binary $0.4-1.2 \mathrm{mg} / \mathrm{l})$, temperature $(5,20,45$ and $\left.60^{\circ} \mathrm{C}\right)$, initial concentration of bacterial biomass ( $\left.0.5-3 \mathrm{~g}\right)$, contact time for defining desorption kinetic, live and dead bacterial biosorption, the effect of desorption agents (EDTA, $\mathrm{CH}_{3} \mathrm{COOH}, \mathrm{NaHCO}_{3}, \mathrm{HNO}_{3}$ $, \mathrm{CH}_{3} \mathrm{COOH}, \mathrm{HCl}, \mathrm{CaCl}_{2}, \mathrm{KCl}, \mathrm{H}_{2} \mathrm{SO}_{4}$ ). To set $\mathrm{pH}, \mathrm{HCl} 0.1 \mathrm{M}$ and $\mathrm{HNO}_{3} 0.1 \mathrm{M}$ had been used. To measure recycling ability, Ni/Cd was washed from bacterial biomass that reached from centrifuge after 60 min adsorption with named desorption agents in above and after washing 3 times with deionized-double distilled water was used again to determine the ability to recapture of metal(s) for 5 times; the final amount gained from average of them $[20,21]$.

\section{Biosorption experiments}

After the experiments, the supernatants were taken from each flask, filtered. Isotherm experiments were carried out in bottle flasks filled with $250 \mathrm{ml}$ of water thoroughly mixed with $0.1 \mathrm{~g}$ of Planococcus biomas at $37^{\circ} \mathrm{C}$ and initial $\mathrm{pH}$ initial close to 6.0. The initial concentrations of metal ions were ranged from $0.4-1.2 \mathrm{mg} / \mathrm{L}$. Singlemetal concentrations in the relevant samples were determined by an atomic absorption spectrophotometer (Chem. Tech. Analytical CTA 2000). The liquid phase was separated from the adsorbent by a filtration system using $0.45 \mu \mathrm{m}$ membranes. The metal uptake at equilibrium was calculated by the following equation: (Equation 1):

$$
q_{e}=\frac{V\left(C_{i}-C_{e}\right)}{W}
$$

Where $q_{\mathrm{e}}$ is the metal uptake $\left(\mathrm{mmol} \mathrm{Cd^{2+ }}\right.$ and $\mathrm{Ni}^{2+}$ adsorbed per $\mathrm{g}$ adsorbent), $V(\mathrm{~L})$ is the solution volume, $W(\mathrm{~g})$ is the amount of sorbent, $C_{\mathrm{i}}(\mathrm{mmol} / \mathrm{L})$ and $C_{\mathrm{e}}(\mathrm{mmol} / \mathrm{L})$ are the initial and equilibrium metal concentration in solution, respectively.

The biosorption results were analyzed using intra-particle diffusion model (weber-moris). This is represented as; (Equation 2)

$$
q_{t}=k_{i d} t^{0.5}+c
$$

where $q_{t}(\mathrm{mg} / \mathrm{g})$ is the amount adsorbed at time $t(\mathrm{~min}), k_{i d}(\mathrm{mg} / \mathrm{g}$ $\left.\min ^{0.5}\right)$ is the rate constant of intra-particle diffusion. $C$ is the value of intercept which gives an idea about the boundary layer thickness, i.e. the larger intercept; the greater is the boundary effect.

Linear form equation, on rearrangement to a linear form, a plot of $1 / \mathrm{q}_{\mathrm{e}}$ against $1 / \mathrm{C}_{\mathrm{e}}$ gives a straight line. (Equation 3 )

$$
\frac{1}{\mathrm{q}_{\mathrm{e}}}=\frac{1}{\mathrm{~b}_{\mathrm{L}} \mathrm{q}_{\mathrm{m}}} \times \frac{1}{C_{e}}+\frac{1}{\mathrm{q}_{\mathrm{m}}}
$$

The linearized Freundlich isotherm model is described by the following equation [22]: Equation (4):

$$
\text { h } q_{e}=\mathrm{h} K_{F}+\frac{1}{n_{F}} \mathrm{~h} C_{e}
$$

where, Ce is the equilibrium concentration of heavy metal in the solution $(\mathrm{mol} / \mathrm{L}), q$ is the adsorption capacity at equilibrium $(\mathrm{mmol} / \mathrm{g})$, $n$ is the Freundlich (1907) constant related to the energy of adsorption and $k$ is a constant. The values of $k$ and $1 / n$ are evaluated from the intercept and the slope, respectively, of the linear plot of $\lg q$ versus $\lg$ Ce based on experimental data [23] Equation 5:

$$
\frac{t}{\mathrm{q}_{\mathrm{t}}}=\frac{1}{h}+\frac{1}{q_{e}} t
$$

Equation (5) does not have the disadvantage of the problem with assigning an effective $\mathrm{q}_{\mathrm{e}}$. If pseudo-second order kinetics is applicable, the plot of $t / q_{t}$ against $t$ of equation (6) should give a linear relationship, from which $\mathrm{q}_{\mathrm{e}}, \mathrm{k}$ and $\mathrm{h}$ can be determined from the slope and intercept of the plot and there is no need to know any parameter beforehand $[24,25]$.

\section{Desorption experiments}

Desorption study was carried out in a similar way to that of absorption studies. A number of authors have investigated the desorption properties of eluting agents for divers' range of biomasses $[25,26]$. Acid solutions may dissolve some types of polysaccharides that contain metal binding sites, as well as the mineral contents of the bio sorbent [26]. Efficiency of various eluents $0.1 \mathrm{M}$ like $\mathrm{HNO}_{3}$, $\mathrm{HCl}$, EDTA, $\mathrm{CaCl}_{2}, \mathrm{KCl}, \mathrm{NaHCO}_{3}$ and $\mathrm{CH}_{3} \mathrm{COOH}$ was used to recover nickel/cadmium from bio-sorbed bacterial cells of the selected strain at $37^{\circ} \mathrm{C}$ and $150 \mathrm{rpm}$. The filtrates were analyzed to determine the concentration of metals ions after desorption. The recovery percentage is obtained from the following relation [27] Equation 6:

$$
\text { desorptionefficiency }(\%)=\frac{D r}{D r} / 100
$$

where Dr is the amount of Cadmium/Nickel ions released in the supernatant solution (mg) and Da represents the Cadmium/Nickel ions initially adsorbed on the bio-sorbent $(\mathrm{mg})$.

\section{Results and discussion}

\section{Effect of $\mathrm{pH}$ on biosorption}

The metal ion binding in biosorption could be attributed to several mechanisms such as ion exchange, complexation, electrostatic attraction, and micro precipitation. The dependence of ion uptake on $\mathrm{pH}$ is related to both the surface functional groups on the bacterial biomass and the metal chemistry in solution. Different bacterial biomass exhibits diverse uptake rates which will have different ranges of $\mathrm{pH}$ for optimum adsorption. 

Studies

The effect of $\mathrm{pH}$ on nickel and cadmium ions biosorption on Planococcus sp. is studied at room temperature by varying the $\mathrm{pH}$ of the solutions. Batch studies results indicate that in the present of the biomass a chemical precipitation occurred since the cadmium, began to precipitate after $\mathrm{pH}$ 7, but the nickel ions began precipitate after $\mathrm{pH}$ 6 (Figure 1). As the $\mathrm{pH}$ increases, the adsorption surface becomes less positive and therefore, electrostatic attraction between the metal ions and sawdust surface increases.

Experimental results show the biosorption of nickel and cadmium ions were increased up to $\mathrm{pH}$ 8. This decreasing of biosorption levels by lowering $\mathrm{pH}$ can be explained due to competition between protons and metal ions for the capturing same sites, which at low $\mathrm{pHs}$, metal ions do not successful.

\section{Kinetic experiments}

To know the biosorption mechanisms and speed of the process, it is important to study the mass transfer and chemical reactions. Therefore, Kinetic is an additional important item which also effect on biosorption because of it identifies the maximum time for adsorption. The time required to attain maximum biosorption depends on the type of bio-sorbent, metal ion, and their combination. The rate of biosorption is rapid initially with almost $90 \%$ of the metal binding because all the active sites are vacant and available for metal ion biosorption. Figure 2 shows a plot of $t / q_{t}$ versus $t$, the kinetics of nickel and cadmium biosorption onto the Planococcus, at $\mathrm{pH}$ 5.5, temperature $37^{\circ} \mathrm{C}$, in deionized water; the contact times to reach the mass balance were obtained at $120 \mathrm{~min}$. In order to determine the effect of contact time on the biosorption of nickel and cadmium ions, the contact time was varied from 20 and 30 min respectively.

\section{Adsorption isotherm}

The nonlinearized adsorption isotherm (Ce versus $\mathrm{q}_{\mathrm{e}}$ ) of nickel and cadmium ions on the biomass of Planococcus biomass were shown in figure 3. These isotherms show that the amount of metal ions adsorbed increased as its equilibrium concentration has increased in solution and reached to a saturation value. The Langmuir constants have been calculated from the corresponding plot (Table 1) for the biosorption of nickel and cadmium ions on the biosorbent. To measure the biosorption capacity of Planococcus biomass on the removal of cadmium and nickel ions from aqueous solution, the Langmuir isotherm model were used. The Langmuir model shows that the biosorption occurs at specific homogeneous sites on the biomass and it is successfully

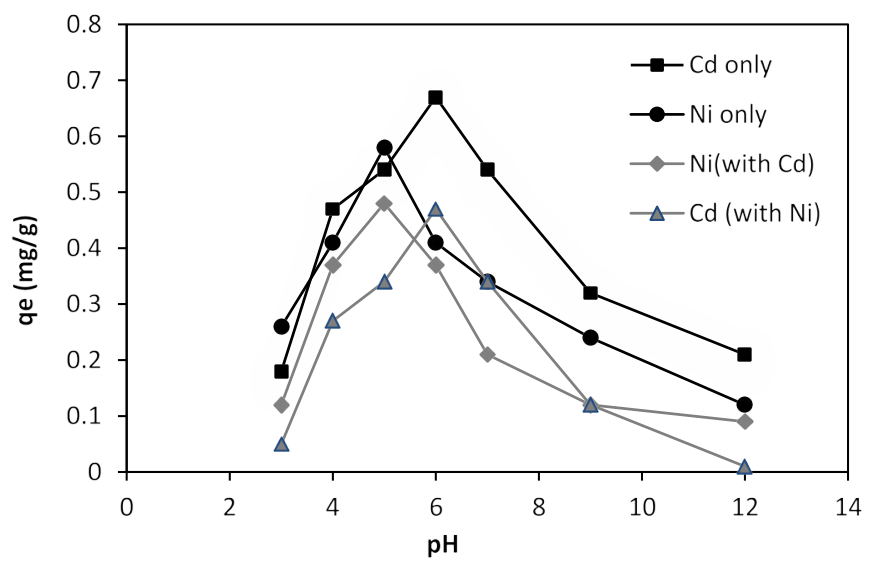

Figure 1. Effect of $\mathrm{pH}$ on the nikcel and cadmium ions (singel and binary form) biosorption by Planococcus $s$.

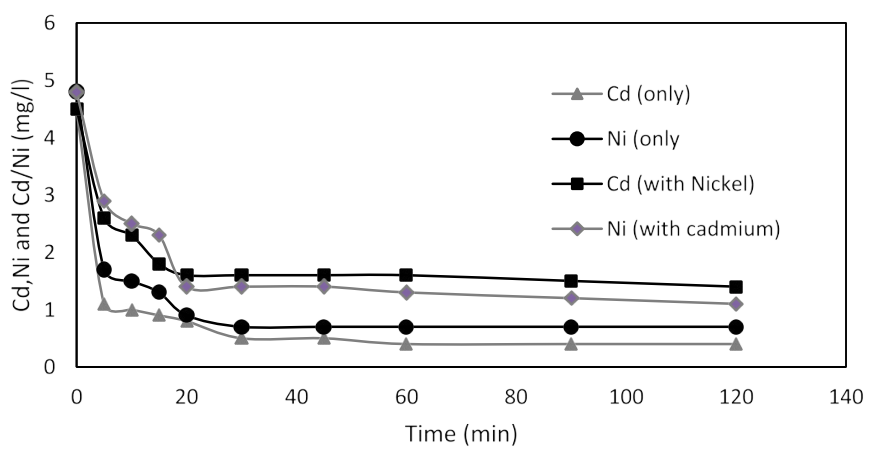

Figure 2. Kinetis of biosorption of nickel and cadmium only and binary by Planococcus $s p$ at $\mathrm{pH} 6$ and $37^{\circ} \mathrm{C}$.

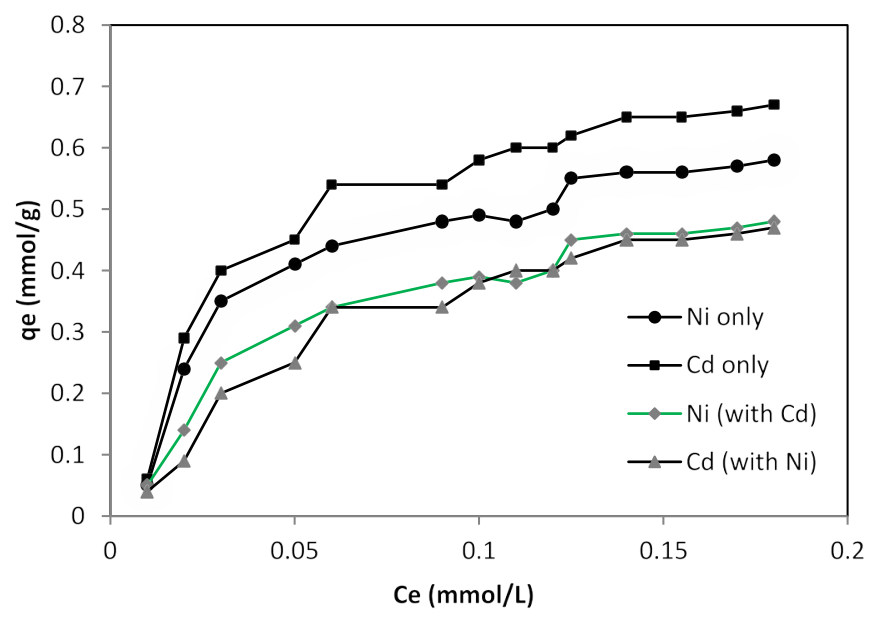

Figure 3. Langmuir isotherm of nickel and cadmium ions in single and binary form biosorbed Planococcus sp biomass.

Table 1. Isotherm parameters of the Langmuir and Freundlich models for the biosorption of single and binary metal system.

\begin{tabular}{|l|c|c|c|c|c|c|}
\hline \multirow{2}{*}{ Ions } & \multicolumn{3}{|c|}{ Langmuir model } & \multicolumn{3}{c|}{ Freundlich model } \\
\cline { 2 - 7 } & $\begin{array}{c}\mathrm{q}_{\mathrm{m}} \\
(\mathrm{mmol} / \mathrm{g})\end{array}$ & $\begin{array}{c}\mathrm{b}_{\mathrm{L}} \\
(\mathrm{L} / \mathrm{mmol})\end{array}$ & $\mathrm{r}^{2}$ & $\mathrm{~K}_{\mathrm{F}}$ & $\mathrm{n}$ & $\mathrm{r}^{2}$ \\
\hline Nickel & 0.588 & 17.921 & 0.992 & 0.571 & 1.718 & 0.961 \\
\hline Cadmium & 0.676 & 26.59 & 0.991 & 0.453 & 1.621 & 0.972 \\
\hline Nickel (with cadmium) & 0.470 & 30.39 & 0.993 & 0.154 & 1.537 & 0.981 \\
\hline cadmium (with nickel) & 0.480 & 21.92 & 0.993 & 0.287 & 1.324 & 0.965 \\
\hline
\end{tabular}

used in many monolayer biosorption processes. The Langmuir model gives a better description of the experimental data $\left(r^{2}=0.990\right)$ and a maximum fixation capacity is deduced to 0.67 and $0.58 \mathrm{mmol} \mathrm{g}^{-1}$ (Table 1) for cadmium and nickel respectively. Sorption capacity values for cadmium and nickel obtained in our study were shown in table 2 .

\section{Characterization of biosorbent using fourier transforms infrared (FTIR) spectroscopy}

The FTIR spectra of metal and metal-loaded biosorbents were used to determine the vibrational frequency changes in the functional groups of the bacterial biomass. The FTIR spectra of raw and loaded bacteria in the range of $400-4000 \mathrm{~cm}^{-1}$ were taken to obtain information about functional group interactions. The infrared spectrum exhibited broad bands centered at $3437 \mathrm{~cm}^{-1}$ assigned to $\mathrm{O}-\mathrm{H}$ and $\mathrm{N}-\mathrm{H}$ stretching, the stretching vibration of $\mathrm{C}=\mathrm{O}$ at $1652 \mathrm{~cm}^{-1}$ and $\mathrm{C}-\mathrm{O}$ stretching of alcoholic groups at $1073 \mathrm{~cm}^{-1}$. The band at $1447 \mathrm{~cm}^{-1}$ was representative of primary bending vibration of $\mathrm{N}-\mathrm{H}$ groups. Comparing the FTIR 
Hoseini AA (2020) Binary biosorption of Cadmium(II) and Nickel(II) onto planococcus sp. isolated from wastewater: Kinetics, equilibrium and thermodynamic Studies

spectra of loaded with raw bacteria displayed significant changes in some of the peaks. The significant shift in the peaks (1652 to 1633 $\left.\mathrm{cm}^{-1}\right),\left(1447\right.$ to $\left.1403 \mathrm{~cm}^{-1}\right)$ and $\left(1073\right.$ to $\left.1043 \mathrm{~cm}^{-1}\right)$ reflects the effect of carboxyl, alcoholic and amine groups on the surface of the bacteria during biosorption.

\section{Biosorption by dead and live biomass; effect of bio-sorbent dose and temperature}

To gain a live bacterial biomass, bacteria cultured in nutrient broth and incubated at $37^{\circ} \mathrm{C}$ in shake culture $(150 \mathrm{rpm})$ and $\mathrm{pH} 6$ for $24 \mathrm{~h}$ and centrifugation at $7000 \mathrm{rpm}$ for $10 \mathrm{~min}$ in $25^{\circ} \mathrm{C}$. After getting live biomass it was put in the oven for $72 \mathrm{~h}$ at $55^{\circ} \mathrm{C}$ and then was powdered to use in the experiments where we need dead bacteria [28]. There are many different methods of dying such as using $\mathrm{Na}$-azid, auto clave, incubator and 2,4 DNF. Na-azid block the metabolic activity of bacteria and auto clave collapses the cell surface structure. The high amount of metals sorption was observed when autoclave was used while using $\mathrm{Na}$ azid exhibited the less amount of sorption (Figure 4). Studies of some researchers have indicated that bio-sorbent dose was also an important parameter affecting biosorption capacity as well as removal efficiency. The results revealed that the biosorption of nickel and cadmium is enhanced with increasing of biomass bacterial dosage (Figure 5). The maximum cadmium and nickel adsorbed at the dosage 1 , and $1.5 \mathrm{~g} / \mathrm{L}$ respectively. In bacterial biomass, higher temperatures usually enhance sorption due to the increased surface activity and kinetic energy of the

Table 2. Comparison of nickel and cadmium biosorption by different bio-sorbent

\begin{tabular}{|l|c|c|c|c|}
\hline Organism & Ion & Metal Uptake (mmol/g) & $\mathbf{p H}$ & References \\
\hline Pencillium simpliccium & $\mathrm{Cd}(\mathrm{II})$ & 0.46 & 6.5 & Pardo et al. 2003 \\
\hline Penicillium chrysogenum & $\mathrm{NI}(\mathrm{II})$ & 0.68 & 6 & Mameri et al. 1999 \\
\hline Rhizobium spp & $\mathrm{Cd}(\mathrm{II})$ & 0.8 & 5.5 & Ozturk, 2007 \\
\hline Enterobacter sp. & $\mathrm{Cd}(\mathrm{II})$ & 0.41 & 6 & Chong et al. 1995 \\
\hline Fucus vesiculosus & $\mathrm{Ni}(\mathrm{II})$ & 0.55 & 3.5 & Holan et al. 1994 \\
\hline Ascophyllum nodosum & $\mathrm{NI}(\mathrm{II})$ & 0.69 & 3.5 & Holan et al. 1994 \\
\hline Bacillus thuringiensis & $\mathrm{NI}(\mathrm{II})$ & 0.77 & 6 & Ozturk 2007 \\
\hline Sargassum filipendula & $\mathrm{Cd}(\mathrm{II})$ & 0.66 & 4.5 & Davis et al. \\
\hline Bacillus thuringiensis & $\mathrm{NI}(\mathrm{II})$ & 0.74 & 7 & Oves et al. 2013 \\
\hline Bacillus thuringiensis & $\mathrm{Cd}(\mathrm{II})$ & 0.52 & 6 & Oves et al. 2013 \\
\hline Echerichia coli & $\mathrm{NI}(\mathrm{II})$ & 0.13 & 3 & Ghoneim et al. 2014 \\
\hline Ulva lactuca & $\mathrm{Cd}(\mathrm{II})$ & 0.38 & 5.5 & Ghoneim et al. 2014 \\
\hline Pseudomonas putida & $\mathrm{Cd}(\mathrm{II})$ & 0.8 & 6.0 & Pardo et al. 2003 \\
\hline Planococcus & $\mathrm{Cd}(\mathrm{II})$ & 0.67 & 6 & In this work \\
\hline Planococcus & $\mathrm{Ni}(\mathrm{II})$ & 0.58 & 5.5 & In this work \\
\hline
\end{tabular}

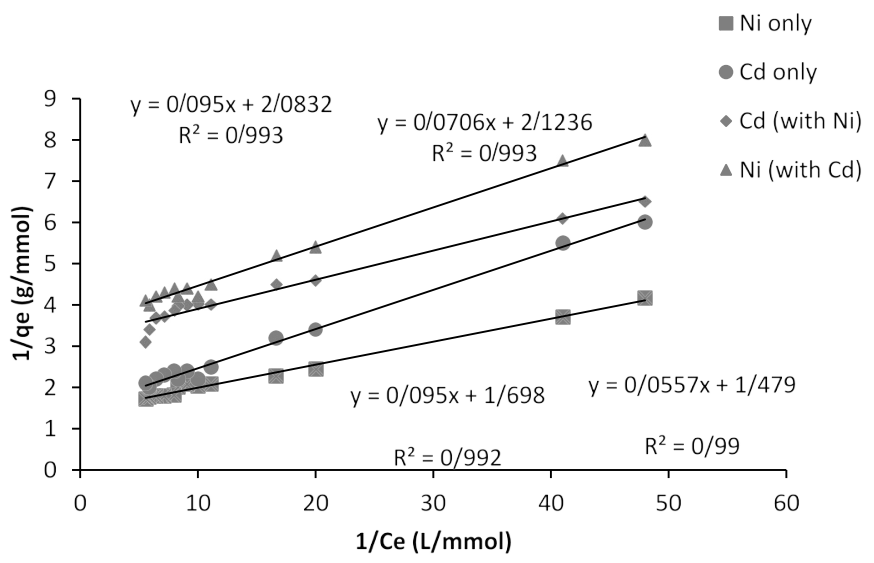

Figure 4. Linearized plot of the Langmuir relationship (1/q vs. 1/Ce) between $\mathrm{q}$ and $\mathrm{Ce}$ of Planococcus $s p$ biomass biosorption isotherm by model binary.

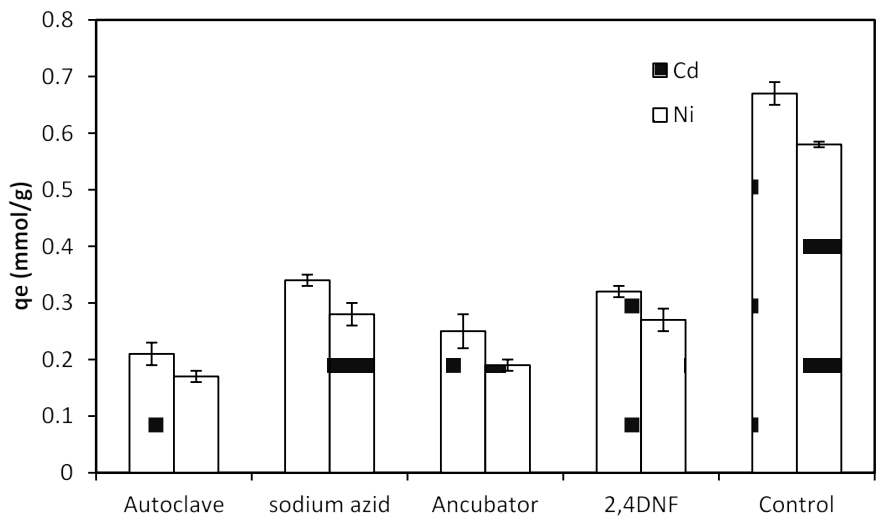

Figure 5. The effect of different methods of death (live and dead biomass) on nickel and cadmium sorption by $1 \mathrm{~g}$ biomass of Planococcus sp biomass in $37^{\circ} \mathrm{C}$ and $\mathrm{pH}=6$.

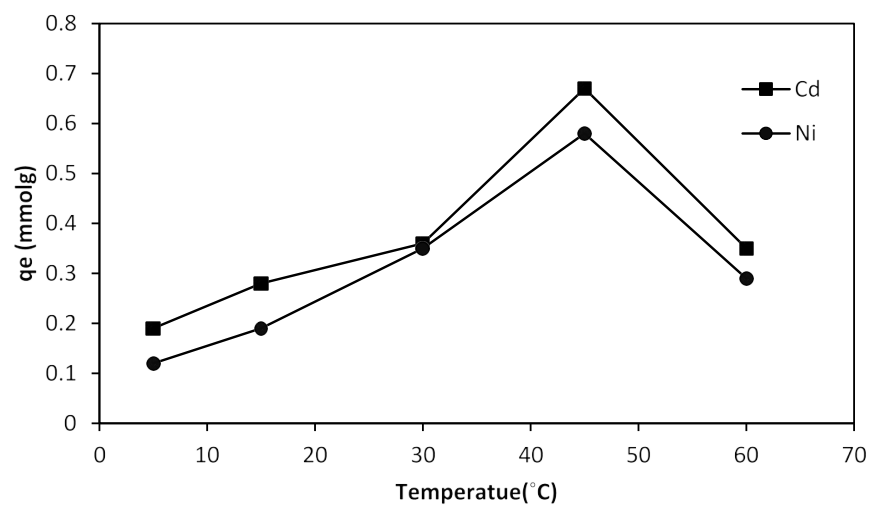

Figure 6. The effect of temperature on sorption of cadmium and nickel by of Planococcus $s p$ biomass.

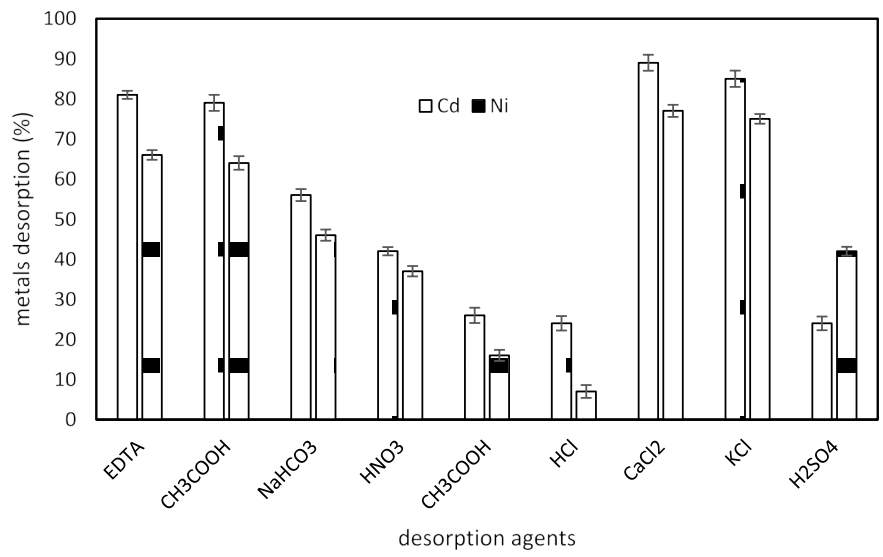

Figure 7. Nickel and cadmium ions recovered by different desorbents in batch tests onto Planococcus sp biomass (1g biomass, $\mathrm{pH} 6$, temperarure $37^{\circ} \mathrm{C}$ ).

solute. Temperature also appears to affect only the reduction of heavy metal uptake by bacteria, especially at very low temperatures and at very high temperatures (Figure 6).

\section{Cadmium and nickel desorption process}

Both the recovery of metal ions and the regeneration of biomass are based on an efficient desorption process, which can complement biosorption research by considering the optimum conditions to release the metal ions already adsorbed onto bio-sorbents. 
Hoseini AA (2020) Binary biosorption of Cadmium(II) and Nickel(II) onto planococcus sp. isolated from wastewater: Kinetics, equilibrium and thermodynamic Studies
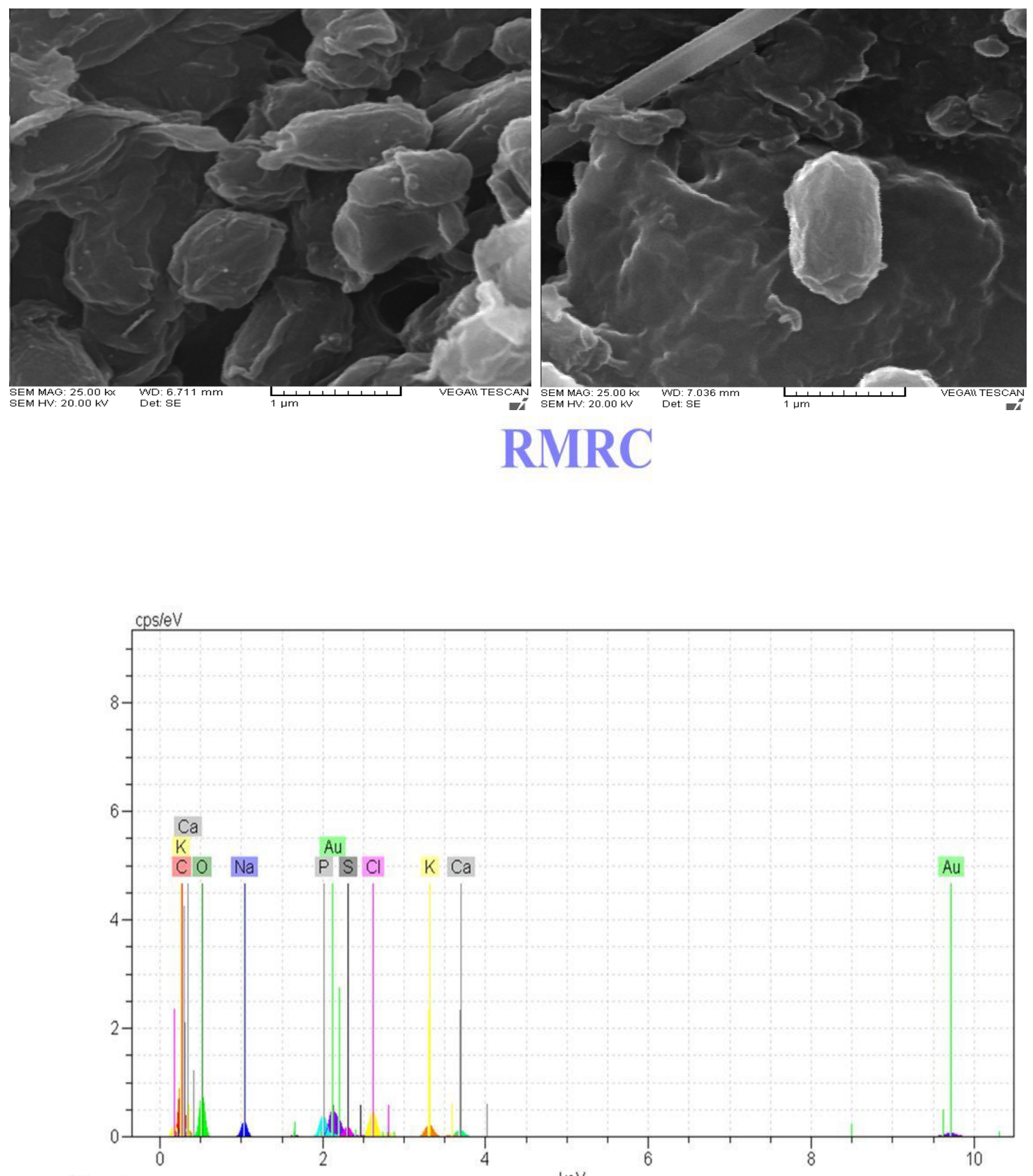

Snectrum

Spectra: 1

\begin{tabular}{|c|c|c|c|c|}
\hline Element & Series & 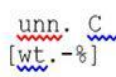 & $\left.\operatorname{mim}_{[w t}^{\text {norm. }} \cdot-8\right]$ & $\begin{array}{l}\text { Atom. C } \\
{[a t .-q]}\end{array}$ \\
\hline Carbon & $\mathrm{K}$ series & 39.59 & 35.97 & 50.39 \\
\hline Oxygen & K series & 45.53 & 41.37 & 43.51 \\
\hline Sodium & K series & 1.88 & 1.71 & 1.25 \\
\hline Phosphorus & $\mathrm{K}$ series & 1.97 & 1.79 & 0.97 \\
\hline Sulfur & $\mathrm{K}$ series & 0.96 & 0.88 & 0.46 \\
\hline Chlorine & K series & 2.87 & 2.61 & 1.24 \\
\hline Potassium & $\mathrm{K}$ series & 1.76 & 1.60 & 0.69 \\
\hline Calcium & $\mathrm{K}$ series & 0.95 & 0.87 & 0.36 \\
\hline Gold & L series & 14.54 & 13.21 & 1.13 \\
\hline
\end{tabular}

Figure 8. The EDX image of Planococcus sp before and after biosorption, and SEM. 

Studies

As revealed in figure 6 shows the percentage of nickel and cadmum ions released by Planococcus pieces after treatment with different de-sorbents. It was observed that the percentage of desorption using distilled water was almost negligible. The possible eluents are dilute mineral acids $\left(\mathrm{HCl}, \mathrm{H}_{2} \mathrm{SO}_{4}\right.$ and $\mathrm{HNO}_{3}$ ), organic acids (citric, acetic and lactic acids), and complexing agents (EDTA, thiosulphate, etc.) for the recovery of the bio-sorbent and metal recovery. The high recovery percentage of nickel and cadmium ions by $\mathrm{KCl}, \mathrm{CaCl}_{2}$ allows the recycling of ions from the biomass in industry (Figure 7).

\section{Scanning alectron microscopy SEM-EDX analysis}

The scanning electron microscopy is an ideal tool for determining changes in cellular morphology. The surface morphology of Planococcus without and with sorption of cadmium/nickel ions during biosorption process was studied with the help of SEM-EDX. The shape changed into a spindle-like structure after metal ions sorption Extra typicality of adsorption has been shown by SEM-EDX images that exhibited the amount of different elements on bacterial cell walls before adsorption and its changes after adsorption. The modifications of bacterial biomass cell surface and precipitation of nickel/cadmium on the cells were revealed by SEM and EDX (Figure 8).

\section{Comparison with other biosorbents}

Table 2 compares the maximum adsorption capacities obtained from this study with some other values reported in the literature. The adsorption capacities for $\mathrm{Cd}(\mathrm{II})$ and $\mathrm{Ni}(\mathrm{II})$ using Planococcus sp. was found to be comparable with many of the reported literature values. However, a direct comparison of experimental data is not possible, due to different experimental conditions such as $(\mathrm{pH}$, temperature, equilibrium time, heavy metal concentration, and biomass dosage).

\section{Conclusion}

Biosorption is a relatively new process that has been shown to have a considerable potential for the efficient removal of pollutants from aqueous effluents. The present study gives the evidence of the possible benefits of using the biomass of Planococcus sp. for the removal of heavy metals from aqueous media. The Langmuir and Freundlich isotherm models were applied to the equilibrium data. Experimental data on deionized water wells are described by the Langmuir model. The maximum biosorption of cadmium and nickel as single ions, and the cadmium/nickel binary densities were reported at $\mathrm{pH} 6,5.5$ and maximum adsorption of $0.67,0.58,0.48$ and $0.47 \mathrm{mmol} / \mathrm{g}$ respectively. Physico-chemical investigations indicate the presence of at least amide, sulfur, phosphates, hydroxyle, carboxylic acid, amine, hydroxide and thiol in surface Planococcus sp. The results obtained though this study support that the Planococcus sp that isolated from waste-water, is effective and low cost bio-sorbent for $\mathrm{Cd}(\mathrm{II})$ and $\mathrm{Ni}$ (II) removal from aqueous solutions.

\section{References}

1. Ahmady-Asbchin S, Andrès $\mathrm{Y}$, Gérente $\mathrm{C}$, Cloirec $\mathrm{P}$ (2008) Biosorption of Cu (II) from aqueous solution by Fucus serratus. Bioresour Technol 99: 6150-6155.

2. Dutton J, Fisher NS (2011) Bioaccumulation of $\mathrm{As}, \mathrm{Cd}, \mathrm{Cr}, \mathrm{Hg}(\mathrm{II})$, and $\mathrm{Me} \mathrm{Hg}$ in killifish (Fundulus heteroclitus) from amphipod and worm prey. Sci Total Environ 409: 3438-3447.

3. Takahashi CK, Turner A, Millward GE, Glegg GA (2012) Persistence and metallic composition of paint particles in sediments from a tidal inlet. Marine Pollution Bulletin 64: $133-137$.

4. Cronje KJ, Chetty K, Carsky M, Sahu JN, Meikap BC (2011) Optimization of chromium (VI) sorption potential using developed activated carbon from sugarcane bagasse with chemical activation by zinc chloride. Desalination 275: 276-284.
5. IARC (2011) Chromium, Nickel and Welding, IARC Monogr Eval Carcinog Risks Hum: Lyon, France. 49: 1-648.

6. Alabi O, Olanrewaju AA, Afolabi TJ (2019) Process optimization of adsorption of $\mathrm{Cr}(\mathrm{VI})$ on adsorbent prepared from Bauhinia rufescens pod by Box-Behnken Design. Separation Sci Technol 55: 47-60.

7. Bouras HD, Yeddou AR, Bouras N, Hellel D, Holtz MD, et al. (2017) Biosorption of Congo red dye by Aspergillus carbonarius M333 and Penicillium glabrum Pg1: Kinetics, equilibrium and thermodynamic studies. J Taiwan Institute Chemical Engineers 80: 915-923

8. Ahmady-Asbchin S, Safari M, Varposhti M (2015a) Biosorption Optimization of $\mathrm{Cr}(\mathrm{VI})$ Using Response Surface Methodology and Thermodynamics Modeling onto Azolla filiculoides. Separation Scie Technol 50: 554-563.

9. Safari M, Ahmady-Asbchin S (2018) Biosorption of zinc from aqueous solution by cyanobacterium Fischerella ambigua ISC67: optimization, kinetic, isotherm and thermodynamic studies. Water Sci Technol 78: 1525-1534.

10. El-Naggar NE, Hamouda RA, Mousa IE, Abdel-Hamid MS, Rabei NH (2018) Biosorption optimization, characterization, immobilization and application of Gelidium amansii biomass for complete $\mathrm{Pb}^{2+}$ removal from aqueous solutions. Sci Rep 8: 13456.

11. Solat S, Roostazaad R, Yaghmaei S (2015) Biosorption of Uranium (VI) from Aqueous Solution by Pretreated Aspergillus niger Using Sodium Hydroxide. Iran J Chem Chem Eng 34: 65-74.

12. Tabaraki R, Nateghi A, Ahmady-Asbchin S (2014) Biosorption of lead (II) ions on Sargassum ilicifolium: Application of response surface methodology. Int Biodeterioration Biodegradation 93: 145-152.

13. Oguz E, Ersoy M (2014) Biosorption of cobalt(II) with sunflower biomass from aqueous solutions in a fixed bed column and neural networks modelling. Ecotoxicol Environ Safety 99: 54-60.

14. Witek-Krowiak A, Szafran RG, Modelski S (2011) Biosorption of heavy metals from aqueous solutions onto peanut shell as a low-cost biosorbent. Desalination 265: 126134

15. Arjomandzadegan M, Rafiee P, Keshavarz-Moraveji M, Tayeboon M, (2014) Efficacy Evaluation and Kinetic Study of Biosorption of Nickel and Zinc by Bacteria Isolated from Stressed Conditions in a Bubble Column. Asian Pac J Trop Med 7: 194-98. [Crossref]

16. Hussain MA, Salleh A, Milow P (2009) Characterization of the Adsorption of the Lead (II) by the Nonliving Biomass Spirogyra neglecta (Hasall) Kützing. Am J Biochemi Biotechnol 5: 75-83.

17. Sulaymon AH, Mohammed AA, Al-Musawi TJ (2013) Removal of lead, cadmium, copper, and arsenic ions using biosorption: equilibrium and kinetic studies. Desalination Water Treatment 51: 4424-4434.

18. Ahmady-Asbchin S, Safari M, Tabaraki R(2015b)Biosorption ofZn(II)by Pseudomonas aeruginosa isolated from a site contaminated with petroleum. Desalination and Water Treatment 54: 3372-3379.

19. Brenner DJ, Krieg NR, Staley JT, Garrity GM (2005) Bergey's Manual of Systematic Bacteriology. Springer, New York, NY, USA.

20. Apiratikul R, Marhaba TF, Wattanachira S, Pavasant P (2004) Biosorption of binary mixtures of heavy metals by green macro alga, Caulerpa lentillifera. Songklanakarin. J Sci Technol 26: 199-207.

21. Al-Qahtani KM (2012) Biosorption of Binary Mixtures of Heavy Metals by Medicago Sativa. World Appl Sci J 16: 465-473.

22. Farooq U, Kozinski JA, Ain-Khan M, Athar M, (2010) Biosorption of heavy metal ions using wheat based biosorbents-a review of the recent literature. Bioresou Technol 101: 5043-53.

23. Gialamouidis D, Mitrakas M, Kyriakides L (2010) Equilibrium, thermodynamic and kinetic studies on biosorption of Mn (II) from aqueous solution by Pseudomonas sp. Staphylococcus xylosus and Blakeslea. J Hazard Mater 182: 672-680.

24. Ho YS, McKay M (1999) Pseudo-second order model for sorption processes. Process Biochem 34: 451-465.

25. Kao WC, Huang CC, Chang JS (2008) Biosorption of nickel, chromium and zinc by MerP-expressing recombinant Escherichia coli. J Hazard Mater 158: 100-106.

26. Vijayaraghavan K, Yun YS (2008) Bacterial biosorbents and biosorption. Biotechnol $A d v$ 26: 266-291. [Crossref] 
Hoseini AA (2020) Binary biosorption of Cadmium(II) and Nickel(II) onto planococcus sp. isolated from wastewater: Kinetics, equilibrium and thermodynamic Studies

27. Arica MY, Arpa C, Kaya B (2003) Comparative biosorption of mercuric ions from aquatic systems by immobilized live and heat-inactivated trametes versicolor and pleurotus sajur-caju. Bioresour Technol 89: 145-154. [Crossref]
28. Velásquez L, Dussan J (2009) Biosorption and bioaccumulation of heavy metals on dead and living biomass of Bacillus sphaericus. J Hazard Mater 167: 713-716. [Crossref]

Copyright: (C2020 Hoseini AA. This is an open-access article distributed under the terms of the Creative Commons Attribution License, which permits unrestricted use, distribution, and reproduction in any medium, provided the original author and source are credited. 